NOTAS 



\title{
THE SOCIAL PERCEPTION OF NATURAL HAZARDS RISK: PORTUGAL AND TUVALU ${ }^{1}$
}

\author{
Rodrigo Rudge Ramos Ribeiro \\ Multidisciplinary Institute for Environment Studies Ramon Margalef \\ University of Alicante \\ Celeste Oliveira Alves Coelho \\ Center for Environment and Marine Studies (CESAM) \\ Department of Environment and Planning \\ University of Aveiro
}

\begin{abstract}
The effects of climate change and sea-level change should cause serious problems for the inhabitants of some small islands such as Tuvalu in the future. As a result of a combination of natural processes and anthropogenic action, the sea-level change creates different impacts.

This research investigates the perception of natural risk and climate change in Portugal and Tuvalu. The perception of the some natural risk, like sea-level rise, can be different of each place. The perception of climate changes in Tuvalu is little known for academic community from University of Aveiro, and they believe that the impacts of sea level rise for Portugal and Tuvalu are not the same. The geographic distance makes an influence in perception of risks; residents far away from this phenomenon present a low level of attention of this phenomenon.
\end{abstract}

Key words: Climate change, Small islands, Tuvalu, Risk, Perception.

\section{RESUMEN}

Los efectos del cambio climático y del nivel del mar deben causar graves problemas para los habitantes de algunas pequeñas islas como Tuvalu en el futuro. Como resultado de una combinación de procesos naturales y acción antropogénica, el cambio del nivel del mar genera un impacto diferente.

Esta investigación aborda la percepción del riesgo natural y del cambio climático en Portugal y Tuvalu. La percepción de algunos riesgos naturales, como la subida del nivel del mar, puede ser distinta para cada sitio. La percepción de los cambios climáticos en

1 This work includes results of research carried out under the Master project in Energy and Environment at University of Aveiro, suported by Programme Alban of high level scholarships to Latin America (reference $n^{\circ}$ : E06M103107BR). 
Tuvalu es poco conocida por la comunidad académica de la Universidad de Aveiro, y creen que los impactos del aumento del nivel del mar para Portugal y Tuvalu no son los mismos. La distancia geográfica tiene una influencia en la percepción del riesgo, a mayor distancia se le da una menor atención.

Palabras clave: Cambio climático, Pequeñas islas, Tuvalu, Riesgo, Percepción.

\section{Introduction}

The effects of climate change are not the same in the entire planet and its consequences are variable in each region of the world. The global warming as an example causes thermal expansion of the water and sea level rise (GIRLING, 2007). There are other effects of the climatic variations such as: heat wave, wild fire in forests and flood (INSTITUTE OF ENVIRONMENT, 2002).

It has happed in the last years a continuous increase of the average temperature in the planet. In Portugal the year of 1997 was the hottest year in the last 70 years, while the six hottest years happens in the last twelve years in the $20^{\text {th }}$ century (SANTOS et al., 2002).

The situation of climate change exists currently in the planet and its damages will increase in the event of nothing being done. The natural phenomenons have complications and different impacts depending on the reality of each country (SCHEFFRAN and BATTAGLINI, 2010). People have different levels of quality life and the impact happens in different ways. Communities with less money recourses are more vulnerable for climate changes (VIDAL, 2007).

The climate change and disruptive nature of these changes could set off an even more serious crisis as conflict within and between societies undermines their stability (WWI, 2008). Insufficient recourses and creations of conflicts, as a consequence of the impact of climate changes create difficulties for social development. The impact in poor countries is more significant. The process of adaption for climate changes becomes so important. In the future the effects of climate change represent an obstacle for human development.

The effective ways of communication (e.g. newspaper, television, Web sites on the Internet) are spreading news about extreme natural phenomenon (e.g. strong winds, flood, drought), and news about the contribution and interference of humans activities in this natural phenomenon's. The dedicated importance of the ways of communication corresponds of an increase of the damage effects felt in areas with higher population density (COELHO, 1988). The media tries to understand the importance of natural phenomenon and its effect and try to transmit this perception to the public.

The perception of climate change is not the same in all the places in the world. And the effects of climate change are different.

«Environmental change is at least partly dependent upon the ways in which people perceive their environment and upon their objectives and aspirations in using, modifying and creating environments in with they can satisfy their wants and their needs» (UNESCO, 1973, p. 10).

\subsection{Portugal}

Portugal is located in Southwestern Europe (Latitude 39 23'59.54”' North, Longitude $8^{\circ} 13^{\prime} 28.03^{\prime \prime}$ West). The population of Portugal was 10,617,575 in 2007 (INE). Of this total $81 \%$ of the population was living in cities. On coastal regions of Portugal lives $75 \%$ of the population (REA, 2003). 
The study about the perception of the population in Águeda, located in the center region of Portugal, about the climate change and the risk of flood in municipality, $71 \%$ of the population inquired recognized the term of climate change. For $94 \%$ of the respondents the climate is changing and $27 \%$ said they had been affected at least once by floods. For the participants the three most worry risks were: extreme temperatures, drought and war/ terrorism. Climate change had an affect in agriculture, for $40 \%$ of the respondents said they had felt the effects of climate change in the agriculture (COELHO et al., 2004).

In a study about the costal risk perception in Aveiro District part of Portuguese coast. The population was conscious of the dangers of these risks, underestimating factors related with urban occupation in areas with potential of danger. The people who live closer to the coast have biggest costal risk perception, while people who live some distance from the coast, have the conscious of these risks. But they do not know a lot about its occurrence, probability and severity (CARVALHO and COELHO, 1998).

\subsection{Tuvalu}

Tuvalu is located in the Pacific Ocean midway between Hawaii and Australia (Latitude $7^{\circ} 6^{\prime} 34.33^{\prime \prime}$ South, Longitude $177^{\circ} 38^{\prime} 57.59^{\prime \prime}$ West). The population of Tuvalu was 11,636 in 2005. Tuvalu is the fourth smallest country in the world. Tuvalu is distributed across nine islands five of which are atolls (Figure 1): Nanumea, Niutao, Nanumaga, Nui, Vaitupu, Nukufetau, Funafuti (capital), Nukulaelae and Niulakita.

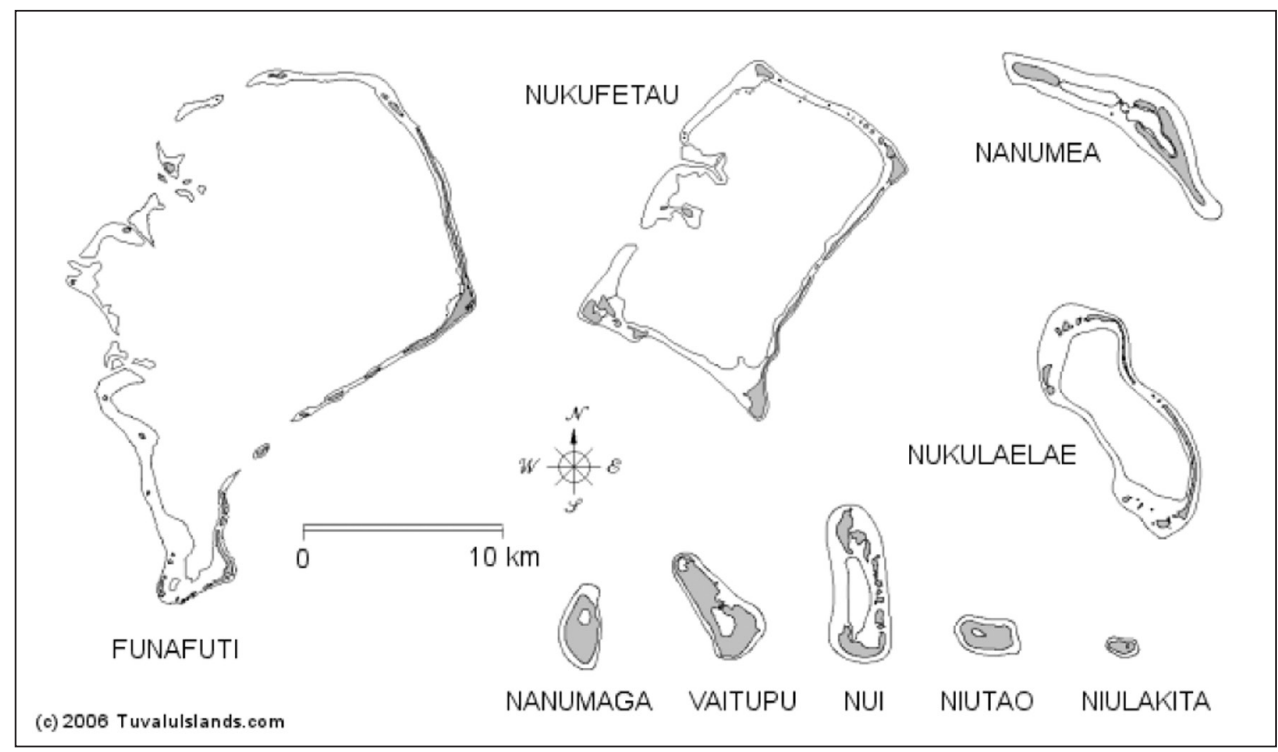

Figure 1 - Map of the Tuvalu.

The islands in tropical oceans are some of the region's most vulnerable to sea-level rise and associated impacts of climate change (CHURCH et al., 2006).

Sea-level change at Funafuti, Tuvalu has been the subject of intense interest as a result of Tuvalu's low-lying nature and reports that flooding is becoming increasingly common. There are two records available at Funafuti: the first record (from a gauge operated by the 
University of Hawaii Sea Level Centre (UHSLC)) commences in 1977 and the second (from a gauge operated by the Australian National Tidal Centre (NTC)) in 1993 (CHURCH et al., 2006). The estimative of relative sea-level rise at Funafuti, Tuvalu is $2 \pm 1 \mathrm{~mm} \mathrm{yr}^{-1}$ (CHURCH et al., 2006). The impacts of sea-level rise in Tuvalu have also been a subject of considerable controversy (ESCHENBACH, 2004; HUNTER, 2004) cited by (CHURCH et al., 2006).

\section{Methodology}

The data for this paper was collected in Portugal and Tuvalu over eight weeks during January 2008 and April 2008, in one virtual data base made for e-Learning (Uoe-L) from University of Aveiro and available in two electronic addresses. With this all people with access to internet had the opportunity to answer the questionnaire.

The questionnaires were made in Portuguese for the persons in Portugal. It was directed for the academic population from the University of Aveiro. Therefore had answed the questionare $3.61 \%$ of the population of the university of the study, it was used the method not probalistic by convenience. The questionnaire was sent to all academic community from University of Aveiro through the Newsletter from University of Aveiro. Some questionnaires were answered on-line and some of than were answered by paper. A total of 550 persons had answed the questionare, of these 301 were answered online.

The questionnaires were made in English for the people in Tuvalu. A total of 23 persons participated in the questionnaires. The questionnaires were spreaded in different way. The principal way used to spread the questinaries, was using the Web site from Tuvalu Islands and in Web forums from Tuvalu. All the questionnaires answered from Tuvalu were answered online.

According to the Web site The Tuvalu Islands where also were made the spread of the questionnaires until April 2008, the Internet service was available only in Funafuti. At this time the Internet service was availed for 200 customers with 32 users were able to be online in the same time. Until when the questionnaires were disponible for answer, 451 persons read or made some connection with the news about the questionnaire on the Web site.

For the data treatment it was used the SPSS (Statistival Package for Social Sciences). It was used questionnaires because of the fact the perception of risk be individual. The evolution of the perception of risk is subjective and varies by individual function.

\section{Results and discussion}

\subsection{Participants in Portugal}

People who had participated in Portugal were asked about climate change, risks and Tuvalu. Of these 550 participants in Portugal, $62 \%$ of these were female, $80 \%$ were students and $66 \%$ of the participants were between 20 and 39 years old.

With relation to the question: «Have you ever heard about Climate Change?», $98 \%$ of the participants had answed «yes». Of these $25 \%$ felt some change in temperature, $21 \%$ felt some change in rainfall and $16 \%$ felt some change in sea-level.

With relation to the question: «Have you ever heard about the country of Tuvalu?», $20 \%$ of the participants had answed «yes». And the $66 \%$ of the participants related Tuvulu with sea-level rise, $30 \%$ of the participants related Tuvulu with climate change and $28 \%$ of the participants related Tuvulu with forced migrations. 


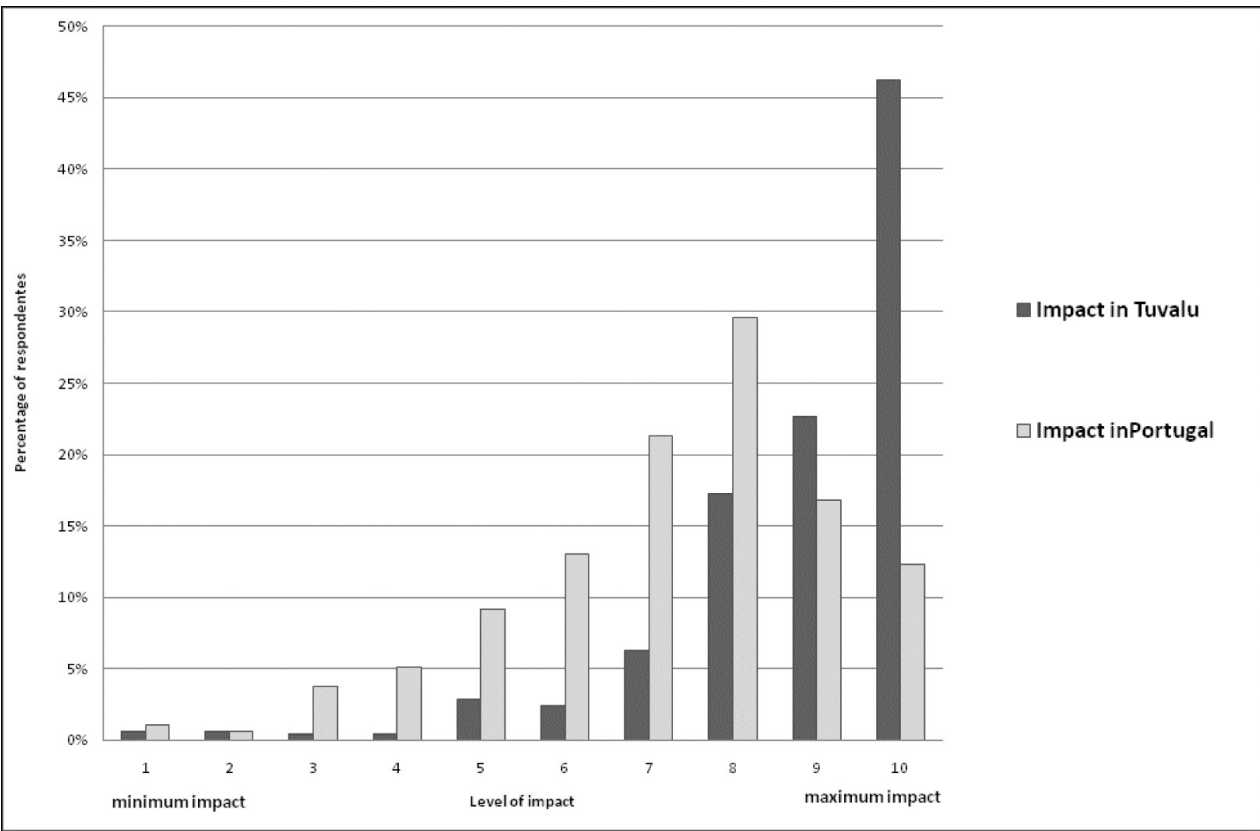

FIGURE 2. Graphic of result to the question about the perception of impact of the sea-level rise in Portugal and Tuvalu (by Portuguese participants).

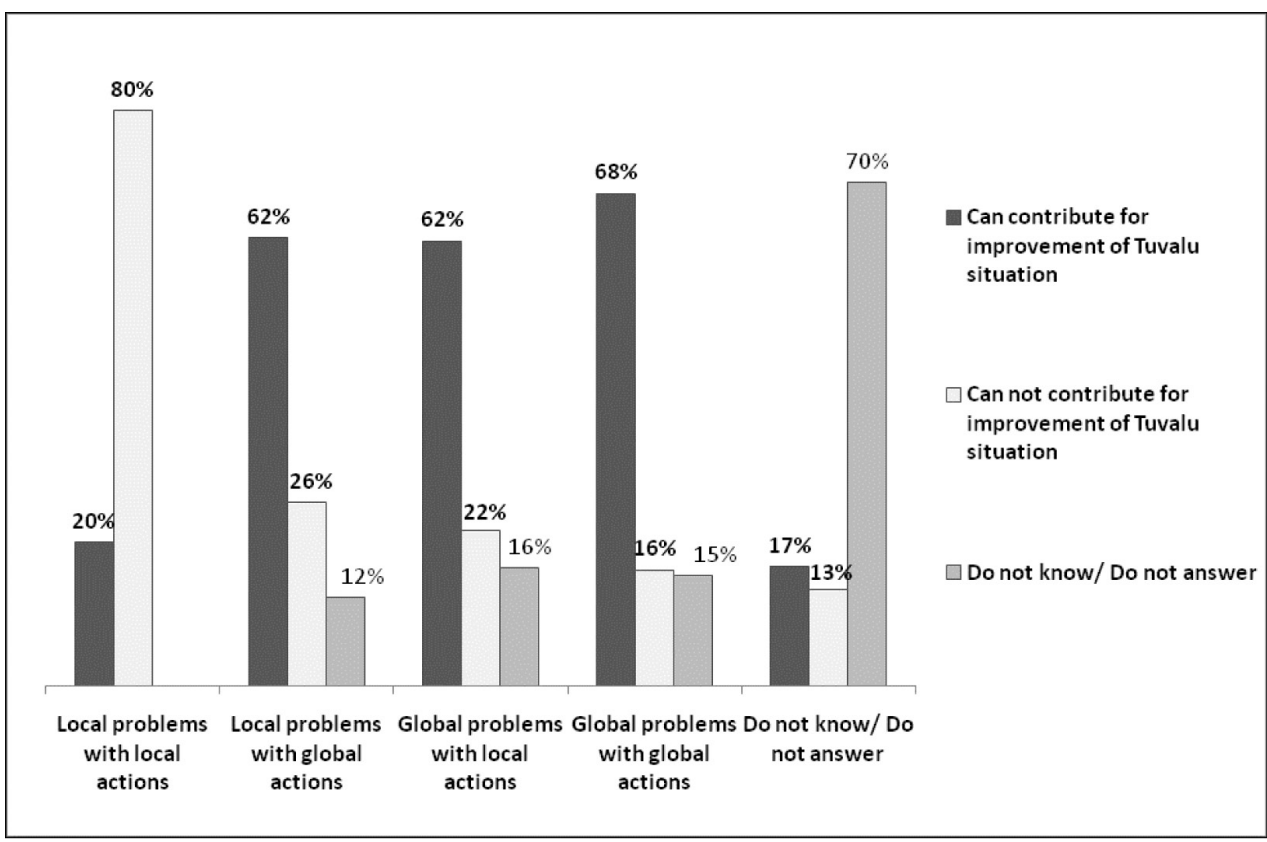

FIGURE 3. Graphic of the result to the question about how should the problems faced by Tuvalu be treating (by Portuguese participants). 
With relation to the question: «Do you think you can contribute for the improvement of Tuvalu sitacion?», 57\% participants answed «yes».

With relation to the question in what level they think Portugal and Tuvalu are suffering the impacts of sea level rise, for the participants in Portugal the impact in Tuvalu is the biggest of the maximum impact (Figure 2$)(1=$ minimum impact and $10=$ maximum impact).

With relation to the question how the problems faced by Tuvalu should be treating. For the participants that believe the problems should be tread as global problems with global actions. For $68 \%$ of these believe this can contribute for the improvement of Tuvalu situation. For the participants that believe the problems should be treated as local problems with local actions. For $80 \%$ of these believe this cannot contribute for the improvement of Tuvalu situation (Figure 3).

The majority of participants do not know Tuvalu, but they have the perception of the level of impact of sea-level rise in Tuvalu, it is bigger than Portugal, for the maximum impacts. In relation to how much they are worried about climate refugees from Tuvalu, $65 \%$ of the participants are worried between 5 and 9 (scale between 1-10).

With relation to the question how should the problems faced by Tuvalu be treating, $47 \%$ of the participants believe the problems should be treated as global problems with global actions.

\subsection{Participants in Tuvalu}

The participants in Tuvalu were asked about climate change, risks and Portugal. Of the total of participants, 20 participants in Tuvalu were considered to analysis. Of these 74\% were male, $40 \%$ were workers and $45 \%$ of the participants were between 20 and 39 years old.

With relation to climate change $90 \%$ of the participants had listen talk about. Of these $90 \%$ felt some change in sea-level, $85 \%$ felt some change in temperature and $80 \%$ felt some change in the sea waves.

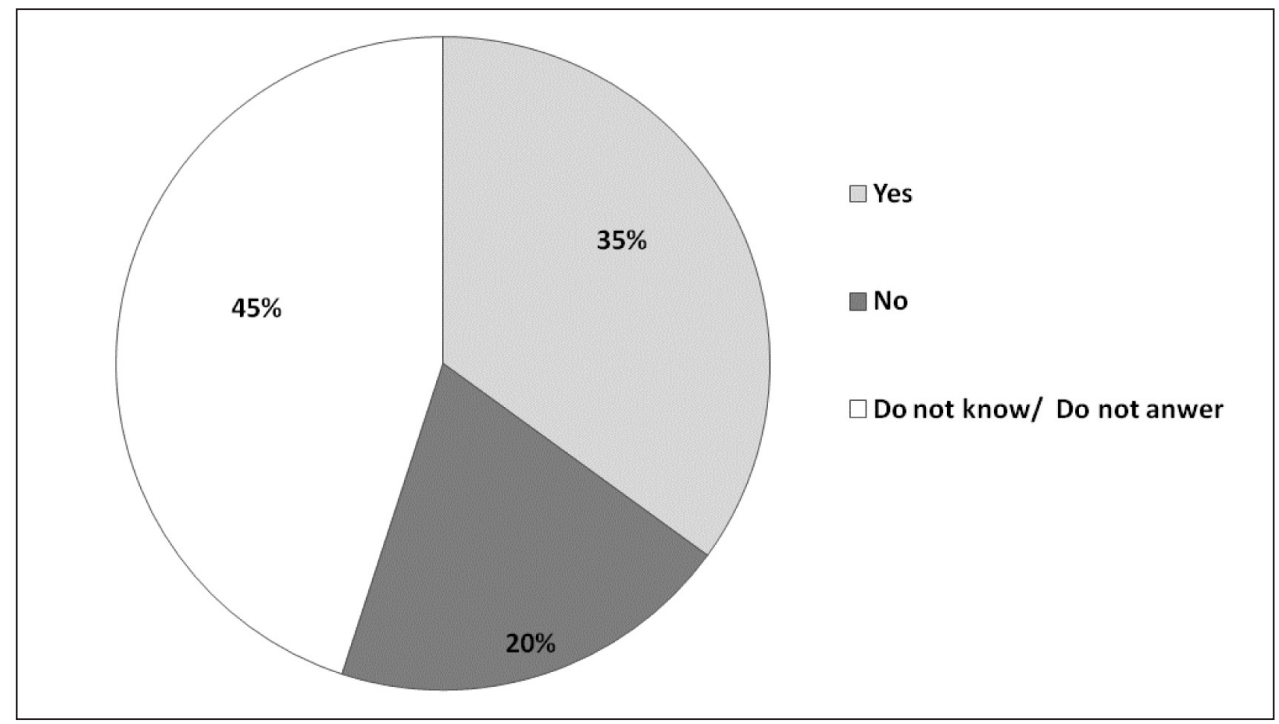

FIGURE 4. The graphic of result to the question about if the scaremongering/ alarmism could be necessary to reduce the global and local risks that we confronted. 
In relation to the opinion of the participants about the evolution of climate change in a near future, $90 \%$ of these believe the impacts should be getting worse.

For the question about the three risks/ situations that worried them most. For the participants $60 \%$ selected coast erosion, $40 \%$ selected extreme temperatures and $30 \%$ selected tsunamis.

As to the relation to the question: «Do you believe the scaremongering/alarmism could be necessary to reduce the global and local risks that we are confronted, for $35 \%$ of the participants answered affirmative and $45 \%$ of the participants answered that they did not know or had no answer to the question (Figure 4).

\subsection{Discussion}

The participants answered in Portugal demonstrated that Tuvalu was not very known by the population from the community at University of Aveiro.

The participants in Portugal, of these $57 \%$ believed could contribute for the improvement of Portuguese situation and $24 \%$ do not know or had no answer to the question. For the majority of the participants the problems faced by Tuvalu should be treating like global problems with global action.

On question about the evaluation of the impacts of sea-level rise by the Portuguese participants, it was observed that the impact in Tuvalu is bigger for the maximum impact when it is compared with the impacts of sea-level in Portugal.

Most of participants that believe could contribute to the situation in Tuvalu understated those problems should be treated as global problems with global actions. And most of the participants that believe could not contribute to the situation in Tuvalu understands those problems should be treated as local problems with local actions.

The condition with the society is exposed to the risk makes an influence in the perception of risks. People do not share the some perception of risks and these cases, due to natural and social conditions. In Tuvalu the sea-level rises have a bigger attention, and the same does not occur in Portugal. The perception of risks is by environment external influences.

The risk of sea-level rise in Tuvalu is about a situation more extreme when it is compared with Portugal. The risk is bigger when they threaten life. Of the $38 \%$ participants in Portugal answered the phenomenon of sea-level rise worries them a lot.

The results in Tuvalu, indicates that people were majority workers and between 30 and 50 years old. The sea-level rise was more cited in the answers ensued by changes in temperature.

The result of this study analyzes two different realities. Remember just that in any situation the question is inevitable a particular social situation (SCHNAPPER, 2000). The questioners are subjects to analysis of particular realities.

\section{Conclusions}

The impact of sea-level rise creates different impacts to each place in the planet and changes the function of aspects as vulnerability faced by sea-level rise (e.g. lost of territory or economics impacts). The perception of the same risk, such as sea-level rise, could be different for each region. The temporal context of the analysis should be considered.

Tuvalu and Portugal it suffering the impacts of climate change and sea-level rise. The floods and storms that occur reduce the resources. There are others cases like Tuvalu, places as the Islands Maldives, Kiribati, Halogen, Bangladesh, Lake Chad, Islands Marshall and 
Tokelau they are also suffering the impacts associated to climate change (CHOMETTE and GARNIER, 2007).

It was not verified the belief to climate change as a reason of God's will. This constatation confirms the theorist that refers the author GIDDENS (1991) about the transition of the preoccupation of the external risks to manufactured risks, related with differences between the traditional culture and industrial society.

The geographic distance makes an influence at the perceptions of risks by the population. People living far a way from the occurrence of this phenomenon presents low level of attention to this phenomenon.

\section{ACKNOWLEDGEMENTS}

The authors are indebted with the participants from Portugal and Tuvalu, with the support UOe-L from the University of Aveiro and also for the Programme AlBan.

\section{REFERENCES}

BECK, U. (1992): Risk Society, Towards a New Modernity. Translated by Mark Ritter. $1^{\circ}$ Edition. Sage Publications Ltd. England, London.

BLAIKIE, P., CANNON, T., DAVIS, I. and WISNER, B. (1996): «Vulnerabilidad: El Entorno Social, Político Y Económico de Los Desastres». Original title: At Risk Translated by: Tercer Mundo Editores. LARED. Viewed 20 February of 2008 (http://www. desenredando.org/public/libros/1996/vesped/index.html).

CARDONA, O. D. A. (2001): «La necesidad de repensar de manera holística los conceptos de vulnerabilidad y riesgo. Una crítica y una revisión necesaria para la Gestión». Centro e Estudos sobre Desastres e Riscos. CEDERI. University of Andes. Bogotá, Colombia. Viewed the february 20th of 2008.

(http://www.desenredando.org/public/articulos/2001/repvuln/index.html).

CARVAlHO, T. M. M. and COELHO, C. O. A. (1998): «Costal Risk Perception: A Case Study in Aveiro District, Portugal». Journal of Hazard Materials 61, pp. 263-270.

COELHO, C. O.A. (1988): «Fenómenos Naturais Ocasionais: Efeitos sobre as Actividades Humanas e o Meio Ambiente». $1^{\circ}$ Conference National about Qualidade do Ambiente. University of Aveiro. 22-24 of February. $3^{\circ}$ Volume. pp. 963-976.

CHOMETTE, G. P. and GARNIER, D. (2007): Du Réchauffement Planétaire Aux Réfugiés Climatiques. Réfugiés Climatiques. Colletif Argos. First Publication, Editor Infolio. ISBN: 978-2-88474-037-1. Gollion, Suisse.

CHURCH, J. A., WHITE, N. J., HUNTER, J. R. (2006): «Sea-Level at Tropical Pacific and Indian Ocean Islands». Jornal Global and Planetary Change 53, pp. 155-168.

FARBOTKO, C. (2004): «Sinking Islands? Tuvalu and Climate Change in the Sydney Morning Herald». Islands of the World VIII International Conference «Changing Islands - Changing Worlds». Kinmen Island (Quemoy), Taiwan.

GIDDENS, A. (1991): As Consequências da Modernidade (The Consequences of Modernity). Traducion by Raul Fiker: Edition UNESP. São Paulo.

GIRLING, R. (2007): Sea Change Bristain's Coastal Catastrophe. Eden Project Books. ISBN: 9781903919774 . First Publication. United Kingdon, 353 pp.

INSTITUTE OF ENVIRONMENT. (2002): Relatório do Estado do Ambiente 2002. Ministério das Cidades, Ordenamento do Território e Ambiente. Edition Instituto do Ambiente, $84 \mathrm{pp}$.

INE (2007): Instituto Nacional de Estatística. Viewed October of 2008 (www.ine.pt/). 
REA, L. M. and PARKER, R. A. (2000): Metodologia de Pesquisa: do Planejamento à Execução. Edition Pioneira. São Paulo.

SANTOS, F. D., FORBES K., MOITA, R. (2002): Climate Change in Portugal Scenarios - Impacts and Adaptation Measures. Project SIAM. Gradativa Publications. Lisbon.

SCHEFFRAN, J. and BATTAGLINI, A. (2010): «Climate and Conflicts: the Security Risks of Global Warming». Reg. Environment Change. DOI 10.1007/s10113-010-0175-8.

SCHNAPPER, D. (2000): A Compreensão Sociológica, Como Fazer Análise Tipológica. Gradativa Publicacions, $87 \mathrm{pp}$.

VIDAL, J. (2007): «How Green are we? - Living our Values: Sustainability Report». Viewed 15 October of 2008.

(http://www.guardian.co.uk/values/sustainability2007/page/0,,2198986,00.html).

UNESCO. (1973): Abraham, A M, Rohmer, E .Rapport Final du Groupe d'Experts sur le Project 13: "La Perception de la Qualité du Milieu dans le Programme sur l'Homme et la Biosphère.» (MAB report no 09). Paris (France). Viewed 26 September of 2008 (http://portal.unesco.org).

WWI (2008): «State of the World 2008. Innovations for a Sustainable Economy». The Worldwach Institute. [Flavin, C., Gardner, G., Prugh, T., Nierenberg, D., Chafe, Z., French, H., Assadourian, E., Talberth, J., Lovins, L.H., Jackson, T., Bergkamp, G., Sadoff, C.W., Bayon, R., Rowe, J., Calder, J., Baue, B., Halle, M.]. Edition 25, 253 pp. 
